\title{
An analysis of retractions of dental publications
}

Clovis Mariano Faggion $\mathrm{Jr}^{1}$, Robert S. Ware ${ }^{2}$, Nikolaos Bakas ${ }^{3}$, Jason Wasiak ${ }^{4,5}$

${ }^{1}$ Department of Periodontology and Operative Dentistry, Faculty of Dentistry, University of Münster, Münster, Germany;

${ }^{2}$ Menzies Health Institute Queensland, Griffith University, Brisbane, Australia;

${ }^{3}$ School of Architecture, Land \& Environmental Sciences, Neapolis University Pafos, Paphos, Cyprus

${ }^{4}$ Austin Health Radiation Oncology, Melbourne, Victoria, Australia

${ }^{5}$ Department of Paediatrics, University of Melbourne, Parkville, VIC, Australia

Corresponding author: Clovis Mariano Faggion Jr, Faculty of Dentistry, University of Münster, Waldeyerstraße 30, 48149 Münster, Germany. Tel +49 (0)251 / 83-47061, Fax +49 (0)251 / 83-47134, Email: clovisfaggion@yahoo.com

Number of words: 2489 without abstract

Short title: Dental retractions

An analysis of retractions of dental publications

\begin{abstract}
Objectives: To comprehensively report on the characteristics of retracted publications in the field of dentistry.

Methods: We searched MEDLINE (via PubMed), PubMed Central, Web of Science and Google Scholar databases for dental retracted articles from database inception to 02 July 2018. In addition, we scanned the search engine, Google Scholar, and the website, Retraction Watch (www.retractionwatch.com), for retracted dental studies. Two researchers independently screened titles, abstracts and full text of search results. Descriptive data was collected on each retracted article including reason for retraction, study type, journal impact factor, and time
\end{abstract}


between publication and retraction. Regression models were used to evaluate the association between journal impact factor and retraction characteristics.

Results: A total of 138 dental retracted studies were included. Reasons for retraction were misconduct $(\mathrm{N}=100,72.5 \%)$, with the most frequently reported misconduct being overlap/plagiarism $(\mathrm{N}=53,38.4 \%)$. In vitro $(28.3 \%)$, case reports $(21.0 \%)$ and narrative reviews $(13.8 \%)$ were study design most frequently identified in retracted studies. The median time between article publication and date of retraction notice was 1 year (interquartile-range [IQR $]=0$ to 2 years). More than half of the retracted articles $(n=82,59.4 \%)$ were cited post-retraction. A retracted article reporting a randomized controlled trial was more likely to appear in journal with higher impact factor than a retracted case report (mean difference $[\mathrm{MD}]=2.2 ; 95 \%$ confidence interval $[\mathrm{CI}]=1.2,3.1$. Articles retracted after 2012 were likely to appear in journals with a lower impact factor $(\mathrm{MD}=-1.3 ; 95 \% \mathrm{CI}=-1.8,0.8)$.

Conclusions: Research misconduct is the main reason for retraction of dental articles. A substantial proportion of these articles were still being cited after their retraction.

Clinical Significance: This report of dental retraction studies informs that more transparency is needed with data reporting in dentistry to improve writing practices in dentistry. A more complete report of retractions and their causes would provide more accurate information to inform researchers and editors to avoid or reduce future cases of retractions. More complete and accurate reporting would increase the overall trust in dental research.

Key-words: Ethics; retracted publication; retraction of publication; conflict of interest

\section{Introduction}

The retraction of a scientific article may occur for a wide variety of reasons that range from plagiarism to data fabrication resulting in the publication of erroneous or irreproducible data 
and subsequent invalidation of the overall study findings [1,2,3]. An earlier meta-analysis suggested that $2 \%$ of scientist admitted to having fabricated, falsified or modified data or results at least once in their careers, and up to $33.7 \%$ admitted to other questionable research practices [4]. Thus, it is likely misconduct has occurred across the entire health care field.

The impact of a retracted article can be significant given the ongoing production of erroneous data can result in spurious clinical decision making that can affect patient care [5]. Conversely, the impact of misappropriating the work of others without acknowledging the original source in text form as seen with plagiarism or the presentation of unreliable findings due to significant methodological processes often linked to honest experimental errors can often be attributed to poor scholarship or absence of knowledge or be difficult to prove [6].

Recent studies have attempted to characterize retraction notices, retracted publications and the role of misconduct in order to gain a more thorough understanding of the impact of retractions and the true extent of misconduct in scholarly research" However, many of these studies have not included articles from the field of dentistry. From within the discipline itself, a number of dental retraction studies have been underpinned by sampling biases (i.e. small sample size) thereby limiting our ability to draw significant conclusions from their result findings $[7,8]$.

Therefore, the aim of this study was to comprehensively report on the characteristics of retracted publications in the field of dentistry. In addition, we aimed to identify the association between retraction characteristics with journal impact factor.

\section{Materials and methods}

\section{Data sources and search strategy}

Two authors (CMF; JW) independently searched MEDLINE (via PubMed), PubMed Central (PMC) and Web of Science for retracted articles published in the field of dentistry from database inception to 02 July 2018. In MEDLINE, we applied the Medical Subject Heading (MeSH) term "dentistry" and the retraction filters, "retraction of publication" and "retracted 
publication". In addition to the databases searched, we scanned the search engine, Google Scholar, and the website Retraction Watch (www.retractionwatch.com) for retracted dental studies. The methods for this review were informed by previous retraction studies [9-14], along with the Cochrane Handbook for Systematic Reviews [15].

\section{Study selection criteria and procedure}

The inclusion criteria were: (a) retracted studies that made reference to teeth and/or the oralmaxillofacial subjects; (b) involved any clinical setting; (c) used any study designs; (d) nonEnglish citations that may have included an English abstract and; (e) retraction notices, with or without accompanying text, to give an overview of the proportion of retracted articles with and without full-text availability.

The reasons for retraction were based on author and journal perspectives as previous published retraction studies $[9,16]$ and included:

1) From the author's perspective:

- Misconduct: which included data fabrication or falsification, fraud, plagiarism, overlap (i.e. duplication of text or images in different publications without appropriate citation) or duplicate publication (i.e. an article published twice as a result of author misconduct in different publications).

- Honest scientific error: defined as mistakes on the part of the author in sampling, methodological procedure or data analysis leading to the publication of erroneous or irreproducible data. Authors, however, had no deliberate intention to report fraudulent information.

- Others: authorship disputes, copyright infringement; peer-review misconduct (for example, using the info as peer reviewer, rejecting the manuscript, and publishing a similar manuscript in another journal).

- Unknown or unclear: where it was not possible to distinguish from misconduct, honest scientific error or other reasons. 
2) From the journal's perspective:

- Published in error: defined as the accidental duplicate publication as a result of publishing error.

- Unknown or unclear: where the reason for retraction was non-informative, poorly defined or not clearly stated.

We evaluated the data from two perspectives (author and journal) to provide clear information on which party played the active role in the misconduct or error. Two authors (CMF; JW) independently screened and reviewed the titles and abstracts against the inclusion criteria. Full-text articles were retrieved and reviewed independently in duplicate by two authors (CMF; JW) for potentially eligible studies. Discrepancies were resolved with consensus by a third author (NB).

\section{Data extraction and collection}

Two authors (CMF; JW) extracted data variables relevant to author demographics (e.g. primary author surname, date of publication, authors country of origin including national income levels), study characteristics (e.g. study design, type of intervention, total number of studies), journal and retraction features (e.g. reason for retraction, journal name, 5-year journal impact factor (IF), article and retraction notice availability, presence of watermark identifying the article as retracted, date of retraction notice, persons/parties responsible for the retraction notice and the number of article citations in Google Scholar). National income level of the country of origin was determined by identifying the country with which the first author of the retracted article was affiliated. World Bank criteria for classifying low-, middle-, and highincome economies were used [17]. The journal IF was determined using the ISI Web of Knowledge (Thomson Reuters) 'Journal Citations Reports. We included the journal IF as a variable because others had found a strong correlation between frequency of retraction and journal IF [18].

\section{Data analysis}


Descriptive statistics for continuous and categorical variables were presented as median with interquartile range (IQR) and frequency (percentage), respectively. The frequency of each retracted publication characteristics was also calculated. In addition, we calculated the median time from publication to retraction from the article's retraction date to the most recent year in which the article was cited. A univariable linear regression model was also used to investigate the association between retracted article characteristics and journal quality as assessed by the 5-year IF. Effect estimates were presented as mean differences (MD) and 95\% confidence intervals (95\%CI). All analyses were performed using Stata Statistical Software v.14.0 (StataCorp, College Station, TX, USA).

\section{Results}

The search in Medline retrieved 157 publications, and 88 were retracted articles. Nineteen retracted articles were found in the PMC, ten in Google Scholar, and three in Web of Science databases. Our manual search of Google and retraction watch websites resulted in 18 more retracted articles. Thus, the final sample of retracted dental articles comprised 138 publications. The list of retracted articles is reported in the supplementary material.

\section{Study characteristics}

The study characteristics of the retracted studies are shown in Table 1. Most retracted studies were published between 2001 and 2016, with a total of 79 (57.2\%) retracted from 2012. In terms of geographic distribution by continent, most retracted research was conducted in Asia $(n=97,70.3 \%)$. A large range of study designs from in vitro $(n=39,28.3 \%)$, case reports $(n=$ $29,21 \%)$ to narrative reviews $(n=19,13.8 \%)$ were identified in the retracted studies. The median number of authors contributing to the original study before retraction was four (IQR 3 to 5).

\section{Retraction features}

The retraction characteristics of the included studies are shown in Table 2. More than half of the studies $(n=100,72.5 \%)$ were retracted due to misconduct, where overlap/plagiarism 
$(\mathrm{N}=53,38.4 \%)$ and inaccurate or falsified conducting or reporting of data $(\mathrm{N}=24,17 \%)$ were the most prevalent form of misconduct. Only eight studies $(5.8 \%)$ were published in error by the journal. The median number of year/s from date of journal publication to date of retraction notice was 1 year (IQR: 0 to 2 years). The largest proportion of retraction notices were issued by journal editors $(\mathrm{N}=118,85.5 \%)$ followed by authors $(\mathrm{N}=14,10.1 \%)$.

Almost all retracted studies $(\mathrm{N}=112,81.2 \%)$ had notification of their retraction freely available as full text through the PubMed database, with remaining notifications available on other databases (i.e. Science Direct) or journal websites. Of these available studies, 79 (70.5\%) had an obvious watermark indicating that the article was retracted. Analysis of citations revealed the identified retracted studies were cited 2110 times in the biomedical literature, with 82 studies $(59.4 \%)$ cited post-retraction.

Table 3 reports the association between characteristics of retracted articles and IF. When the association between study characteristics and journal quality was investigated, in-vitro $(\mathrm{MD}=1.9 ; 95 \% \mathrm{CI}=1.2,2.6)$ and randomized studies $(\mathrm{MD}=2.2 ; 95 \% \mathrm{CI}=1.2,3.1)$ were more likely to be retracted from journals with higher IF than case reports. Table 4 reports the association between retraction-related study characteristics and IF. Articles retracted after 2012 were likely to appear in a journal with a lower IF (MD=-1.3; 95\%CI $=-1.8,-0.8)$. Retracted articles withdrawn by authors were published in journals with higher IF than articles withdrawn by editors $(\mathrm{MD}=1.3 ; 95 \% \mathrm{CI}=0.4,2.2)$. Furthermore, authors coming from high income countries were more likely to be retracted from journals with higher IFs $(\mathrm{MD}=1.5$; $95 \% \mathrm{CI}=1 \cdot 0,2.1)$.

\section{Discussion}

The aim of this study was to comprehensively report on the characteristics of retracted publications in the field of dentistry. Our findings showed that misconduct in the form of overlap and plagiarism accounted for $72.5 \%$ of retracted studiers followed closely by $9.4 \%$ for publications involving authorship disputes, copyright infringement or peer-review misconduct 
and $3.6 \%$ for honest scientific error. In addition, we were unable to account for reasons of retraction in 12 studies $(8.7 \%)$. Most of the retracted studies were still being hosted online and freely available via PubMed, but with a watermark stamped over each page. Whilst the median number of year/s from date of journal publication to date of retraction notice was 1 year, analysis of citations before and after retraction revealed that 82 studies $(59.4 \%)$ continued to be cited post-retraction.

Our results were in keeping with other retraction-based studies, which showed that the majority of retractions were a result of misconduct, with rates varying from $59 \%$ to $72 \%$ $[9,10,12,13,16,19]$. The additional finding that $8.7 \%$ of studies could not be allocated a retraction category was also seen in studies with rates reported from $4.9 \%$ to $22 \%$ [20,21]. Hesselman et al. [22] suggested that this knowledge gap in retraction studies was largely due in part to journals providing inconsistent or ambiguous information.

However, our findings differed from other dental retraction studies. In the study by Nogueira et al (2017), the authors reported on 72 retracted articles and attributed the rate to redundant publication $(20.8 \%)$ and plagiarism (18.1\%) and less so with misconduct (13.8\%) or overlap $(13.6 \%)$. These differences may have stemmed from the variations seen sample sizes and retraction definitions. In the second study by Shamim (2018) [8], the small sample size of 15 studies precluded us from undertaking any formal comparisons; however, the author cited duplicate publication, plagiarism and authorship disputes as the major causes for the retracted studies.

The median number of year/s from date of journal publication to date of retraction notice was 1 year as seen with previous studies [23]. Wang et al. [13] suggested that this retraction lag represented a significant delay in the identification of invalid studies, and was in direct opposition to the Committee on Publication Ethics (COPE) guidelines, which proposed the urgent need to publish retraction notices in order to help minimise the harmful effects from misleading publications. More importantly, this time period could have been delayed even 
further given the protracted delays seen in PubMed ranging from 6-35 months with time to MeSH indexing [24].

In terms of geographic distribution by continent, most retracted research from overlap/plagiarism [25,26] was conducted in Asia. More specifically, authors from India represented one-third of all retracted studies for either overlap/plagiarism. These findings were similar to Amos 2014 [20] who also reported the slightly higher rate of 37\% from India authors. We also observed that articles published in journals with lower IF were commonly retracted because of overlap/plagiarism. However, the most common reason for retraction among articles published in journals with higher IF was inaccurate or falsified conducting or reporting. These results were in line with a previous study [10] that found fraud or suspected fraud as the main reason for retraction in journals with higher IF, and plagiarism/duplication as the primary reason for retraction in journals with lower IF.

Analysis of citations after retraction revealed that $60 \%$ of articles continued to be cited after retraction as noted previously by others [27-28]. In the study by Budd et al. 1999 [27], the authors found 235 retracted studies to have 2034 post-retraction citations. Further analysis of these citations revealed that most authors did not critique or comment on its retraction status). In a second study by Neale et al. 2010 [28], the authors showed that a sample of 102 studies affected by misconduct was still able to report an average rate of 26 citations. Along with our citations results, these findings inferred that many readers might not have been exposed to the retraction notification or details.

The study also had a number of strengths. First, our systematic result findings continued to raise the awareness of this topic for readers, collaborators or investigators who may use or cite these works. Second, our sample consisted of retracted dental articles from various publication sources. Third, we were able to explore the association between retraction characteristics and journal IF. We were also mindful of our study limitations. First, the study was restricted by the small sample size, which limited our ability to draw significant conclusions from our results. 
Second, almost $9 \%$ of studies were not available online thereby restricting our ability to confirm the specific reason for retraction. Third, the time delays present with the indexation of studies and retraction notices in PubMed may have missed potentially relevant studies.

Our sample of 138 retracted articles suggests that the number of retracted articles represents a minor part of dental articles published over the years. However, this number might be underestimated by the difficulty to identify retracted articles in the published literature. Some of articles published in journals indexed in PubMed and Web of Science databases were not identified by using the specific filters in these databases. The lack of sensitivity of these filters suggests the need for the development of specific search strategies for comprehensively identifying retracted articles.

Methods to date by scientific journals to better identify and report cases of retraction have included the use of software to identify plagiarism [29], the submission of "raw data" [30] is thoroughly analyzed by editors and reviewers. This measure would urge cautionary behavior in authors contemplating the fabrication of data. Finally, as suggested by the COPE guidelines [1], editors should also provide more comprehensive reporting on the reasons for retraction. The retraction note should explicitly state the reason for retraction. The note should also be added as an extension to the retracted manuscript (i.e., incorporated into the watermarked article).

\section{Conclusions}

\section{Acknowledgements}

Authors of this study have no conflict of interest

Our study identified that methodological misconduct was the most commonly known reason for dental retractions. Although our sample size showcased how rare this event was within the published literature, it is recommended that dental journals, editors, and professional bodies improve writing practices, highlight retraction notifications and foster the uptake of publication and research ethics. These measures would help minimise the potential impact retracted studies may have on clinical practice and research outcomes.

\section{References}

Committee

on

Publication

Ethics

(COPE)

https://publicationethics.org/resources/guidelines [accessed on 14 May 2018]. 
[2] V. Pupovac, D. Fanelli. Scientists Admitting to Plagiarism: A Meta-analysis of Surveys, Sci. Eng. Ethics. 21(2015) 1331-52.

[3] D.R. Miller. Publication fraud: implications to the individual and to the specialty, Curr. Opin. Anaesthesiol. 24(2011) 154-9.

[4] D. Fanelli. How many scientists fabricate and falsify research? A systematic review and meta-analysis of survey data, PLoS. ONE. 4(2009) e5738.

[5] S.L. George. Research misconduct and data fraud in clinical trials: prevalence and causal factors, Int. J. Clin. Oncol. 21(2016) 15-21.

[6] M. Hosseini, M. Hilhorst, I. de Beaufort, D. Fanelli. Doing the Right Thing: A Qualitative Investigation of Retractions Due to Unintentional Error, Sci. Eng. Ethics. 24(2018) 189-206.

[7] T.E. Nogueira, A.S. Gonçalves, C.R. Leles, A.C. Batista, L.R. Costa. A survey of retracted articles in dentistry, BMC. Res. Notes.10 (2017) 253.

[8] T. Shamim. Data regarding articles retracted from PubMed indexed dental journals from India. Data Brief. 18 (2018) 1069-1072

[9] A. Bozzo, K. Bali, N. Evaniew, M. Ghert. Retractions in cancer research: a systematic Survey, Res. Integr. Peer. Rev. 2 (2017) 5

[10] F.C. Fang, R.G. Steen, A. Casadevall. Misconduct accounts for the majority of retracted scientific publications, Proc. Natl. Acad. Sci. U S A. 109(2012) 17028-33.

[11] E. Wager, P. Williams. Why and how do journals retract articles? An analysis of Medline retractions 1988-2008, J.Med. Ethics. 37(2011) 567-70.

[12] J. Yan, A. MacDonald, L.P. Baisi, N. Evaniew, M. Bhandari, M. Ghert. Retractions in orthopaedic research: A systematic review, Bone. Joint. Res. 5(2016) 263-8.

[13] J. Wang, J.C. Ku, N.M. Alotaibi, J.T. Rutka. Retraction of Neurosurgical Publications: A Systematic Review, World. Neurosurg. 103 (2017) 809-14

[14] J. Wasiak, D. Hamilton, F. Farshad, C.M. Faggion Jr. Surveying retracted studies and notices within the field of radiation oncology. Int J Radiat Oncol Biol Phys. (2018) 10.1016/j.ijrobp.2018.06.028

[15] J.P.T. Higgins, S. Green (editors). Cochrane Handbook for Systematic Reviews of Interventions Version 5.1.0 [updated March 2011]. The Cochrane Collaboration, 2011.Available from www.handbook.cochrane.org.

[16] J.C. Samp, G.T. Schumock, A.S. Pickard. Retracted publications in the drug literature, Pharmacotherapy. 32(2012) 586-95. 
[17]

World

Bank

Country

Classification.

2017.

https://datahelpdesk.worldbank.org/knowledgebase/articles/906519[accessed on 14 May 2018].

[18] S. Saha, S. Saint, D.A. Christakis. Impact factor: a valid measure of journal quality? J Med Libr Assoc. 91(2003) 42-6.

[19] R. Rai, S. Sabharwal. Retracted Publications in Orthopaedics: Prevalence, Characteristics, and Trends, J. Bone. Joint. Surg. Am. 99(2017) e44.

[20] K.A. Amos. The ethics of scholarly publishing: exploring differences in plagiarism and duplicate publication across nations, J. Med. Libr. Assoc. 102(2014) 87-91.

[21] E. Bilbrey, N. O'Dell, J. Creamer. A novel rubric for rating the quality of retraction notices, Publications. 2 (2014) 14-26.

[22] F. Hesselmann, V. Graf, M. Schmidt, M. Reinhart. The visibility of scientific misconduct: A review of the literature on retracted journal articles, Curr. Sociol. 65(2017) 814-845.

[23] E.C. Moylan, M.K. Kowalczuk. Why articles are retracted: a retrospective cross-sectional study of retraction notices at BioMed Central, BMJ. Open. 6(2016) e012047.

[24] A.N. Irwin, D. Rackham. Comparison of the time-to-indexing in PubMed between biomedical journals according to impact factor, discipline, and focus, Res. Social. Adm. Pharm. 13(2017) 389-393.

[25] R.M. Almeida, K. de Albuquerque Rocha, F. Catelani, A.J. Fontes-Pereira, S.M. Vasconcelos. Plagiarism Allegations Account for Most Retractions in Major Latin American/Caribbean Databases, Sci. Eng. Ethics. 22(2016):1447-1456.

[26] S. Stretton, N.J. Bramich, J.R. Keys, J.A. Monk, J.A. Ely, C. Haley, M.J. Woolley, K.L. Woolley. Publication misconduct and plagiarism retractions: a systematic, retrospective study, Curr. Med. Res. Opin. 28(2012) 1575-83.

[27] J.M. Budd, M. Sievert, T.R. Schultz, C. Scoville. Effects of article retraction on citation and practice in medicine, Bull. Med. Libr. Assoc. 87(1999) 437-43.

[28] A.V. Neale, R.K. Dailey, J. Abrams. Analysis of citations to biomedical articles affected by scientific misconduct, Sci. Eng. Ethics. 16(2010) 251-61.

[29] T.C. Long, M. Errami, A.C. George, Z. Sun, H.R. Garner. Scientific integrity. Responding to possible plagiarism. Science 323(2009) 1293-4

[30] A.J. Vickers. Sharing raw data from clinical trials: what progress since we first asked, "Whose data set is it anyway?" Trials. 17(2016) 227.

Table 1. Characteristics of 138 retracted articles 
Characteristic

Frequency (\%)

\begin{tabular}{cc}
\hline Date of publication & \\
Up to 2012 & $85(61.6)$ \\
After 2012 & $53(38.4)$ \\
Continent of first author & \\
Asia & $97(70.3)$ \\
Other & $33(23.9)$ \\
Unknown & $8(5.8)$ \\
& \\
Study design & \\
Case report & $29(21.0)$ \\
Case-series & $9(6.5)$ \\
Cross-sectional & $12(8.7)$ \\
Case-control & $1(0.7)$ \\
Randomized trial & $12(8.7)$ \\
Narrative review & $19(13.8)$ \\
Letter to the editor & $1(0.7)$ \\
In-vitro & $39(28.3)$ \\
Animal study & $3(2.2)$ \\
Not stated & $13(9.4)$ \\
Type of journal & \\
Medical & \\
Dental & $50(36.2)$ \\
\end{tabular}


Table 2. Retraction-related study characteristics of 138 retracted articles

\begin{tabular}{|c|c|}
\hline Retraction characteristics & Frequency $(\%)$ \\
\hline \multicolumn{2}{|l|}{ Date of retraction } \\
\hline Up to 2012 & $59(42.8)$ \\
\hline After 2012 & $79(57.2)$ \\
\hline \multicolumn{2}{|l|}{ Reason for retraction } \\
\hline \multicolumn{2}{|l|}{ Author perspective: } \\
\hline Misconduct & $100(72.5)$ \\
\hline Scientific error & $5(3.6)$ \\
\hline Others* & $13(9.4)$ \\
\hline Unknown or unclear & $12(8.7)$ \\
\hline \multicolumn{2}{|l|}{ Journal perspective: } \\
\hline \multicolumn{2}{|l|}{ Duplicate publication } \\
\hline Unknown or unclear* & $8(5.8)$ \\
\hline \multicolumn{2}{|l|}{ Who retracted } \\
\hline Editor & $118(85.5)$ \\
\hline Author & $14(10.1)$ \\
\hline Not stated & $6(4.4)$ \\
\hline \multicolumn{2}{|l|}{ Watermark } \\
\hline Yes & $79(57.3)$ \\
\hline No & $33(23.9)$ \\
\hline $\mathrm{NA}^{*}$ & $26(18.8)$ \\
\hline \multicolumn{2}{|l|}{ Full-text available } \\
\hline Yes & $112(81.2)$ \\
\hline No & $26(18.8)$ \\
\hline \multicolumn{2}{|l|}{ Income } \\
\hline Low Income & $2(1.5)$ \\
\hline Middle income & $90(69.2)$ \\
\hline High income & $38(29.2)$ \\
\hline Median (IQR)/article & $7(2-16)$ \\
\hline \multicolumn{2}{|c|}{ Time from publication to retraction (years) } \\
\hline & $1(0-2)$ \\
\hline
\end{tabular}

IQR: interquartile range

Others*: includes authorship disputes, copyright infringement; peer-review misconduct (for example, using the info as peer reviewer, rejecting the manuscript, and publishing a similar manuscript in another journal) NA*: watermark was not counted because the full-text was not available 
Unknown or unclear*: when there was no or unclear information on the reason for retraction

Table 3. Association between characteristics of retracted articles and impact factor

\begin{tabular}{ccc}
\hline & $\begin{array}{c}\text { Impact Factor } \\
\text { Mean (SD) }\end{array}$ & $\begin{array}{c}\text { Mean difference }(95 \% \\
\text { CI) }\end{array}$ \\
\hline Date of publication & $2.0(1.8)$ & ref. \\
Up to 2012 & $1.0(1.2)$ & $-1.0(-1.6,-0.5)$ \\
After 2012 & & ref. \\
Continent of first author & $1.3(1.5)$ & $1.2(0.6,1.8)$ \\
Asia & $2.5(1.5)$ & $1.3(0.2,2.5)$ \\
Other & $2.6(2.3)$ & \\
Unknown & & ref. \\
Study design & & $-0.3(-1.4,0.7)$ \\
Case report & $0.6(0.9)$ & $0.1(-0.9,1.1)$ \\
Case-series & $0.3(0.7)$ & $0.8(-2.1,3.7)$ \\
Cross-sectional & $0.8(1.3)$ & $2.2(1.2,3.1)$ \\
Case-control & 1.4 & $0.7(-0.1,1.6)$ \\
Randomized trial & $2.8(2.1)$ & $3.9(1.0,6.8)$ \\
Narrative review & $1.4(1.9)$ & $1.9(1.2,2.6)$ \\
Letter to the editor & 4.5 & $1.4(-0.3,3.1)$ \\
In-vitro & $2.5(1.5)$ & $1.2(0.3,2.2)$ \\
Animal study & $2.1(0.5)$ & \\
Not stated & $1.8(1.3)$ & ref. \\
Type of journal & & $0.3(-0.3,0.9)$ \\
Medical & $1.5(1.7)$ & \\
Dental & $1.8(1.6)$ &
\end{tabular}

SD: standard deviation CI: confidence interval ref.: reference 
Table 4. Association between retraction-related study characteristics and impact factor

\begin{tabular}{|c|c|c|}
\hline & $\begin{array}{l}\text { Impact factor } \\
\text { Mean (SD) }\end{array}$ & Mean difference $(95 \% \mathrm{CI})$ \\
\hline \multicolumn{3}{|l|}{ Date of retraction } \\
\hline Up to 2012 & $2.4(1.9)$ & ref. \\
\hline After 2012 & $1.1(1.2)$ & $-1.3(-1.8,-0.8)$ \\
\hline \multicolumn{3}{|l|}{ Reason for retraction } \\
\hline \multicolumn{3}{|l|}{ Author perspective: } \\
\hline Misconduct & $1.7(1.8)$ & ref. \\
\hline Scientific error & $2.6(1.8)$ & $1.0(-0.5,2.5)$ \\
\hline Others* & $1.1(1.1)$ & $-0.5(-1.5,0.4)$ \\
\hline Unknown or unclear & $1.7(1.1)$ & $0.0(-1.0,1.0)$ \\
\hline \multicolumn{3}{|l|}{ Journal perspective: } \\
\hline Duplicate publication & $1.5(1.3)$ & $-0.2(-1.4,1.0)$ \\
\hline Unknown or unclear* & $\mathrm{n} / \mathrm{a}$ & $\mathrm{n} / \mathrm{a}$ \\
\hline \multicolumn{3}{|l|}{ Who retracted } \\
\hline Editor & $1.5(1.6)$ & ref. \\
\hline Author & $2.8(1.8)$ & $1.3(0.4,2.2)$ \\
\hline Not stated & $1.8(0.9)$ & $0.3(-1.0,1.6)$ \\
\hline \multicolumn{3}{|l|}{ Watermark } \\
\hline Yes & $1.4(1.6)$ & ref. \\
\hline No & $1.9(1.7)$ & $0.5(-0.2,1.2)$ \\
\hline NA* & $1.2(1.4)$ & $-0.2(-1.0,0.7)$ \\
\hline \multicolumn{3}{|l|}{ Full-text available } \\
\hline Yes & $1.7(1.7)$ & ref. \\
\hline No & $1.2(1.4)$ & $-0.5(-1.2,0.2)$ \\
\hline \multicolumn{3}{|l|}{ Income } \\
\hline Low Income & 0.0 & $-1.2(-3.2,0.9)$ \\
\hline Middle income & $1.2(1.3)$ & ref. \\
\hline High income & $2.7(1.7)$ & $1.5(1.0,2.1)$ \\
\hline \multicolumn{3}{|l|}{ Number of citations } \\
\hline Median (IQR)/article & & $0.04(0.03,0.06)$ \\
\hline \multicolumn{3}{|c|}{$\begin{array}{c}\text { Time from publication to retraction } \\
\text { (years) }\end{array}$} \\
\hline Median (IQR) & & $0.19(0.06,0.32)$ \\
\hline
\end{tabular}


SD: standard deviation

CI: confidence interval

ref.: reference

n/a: not applicable as no events in unknown/unclear category

IQR: interquartile range

Others*: includes authorship disputes, copyright infringement; peer-review misconduct (for example, using the info as peer reviewer, rejecting the manuscript, and publishing a similar manuscript in another journal)

NA*: watermark was not counted because the full-text was not available

Unknown or unclear*: when there was no or unclear information on the reason for retraction 


\section{References of included retracted dental articles $(\mathrm{N}=138)$ (when available, retraction notice (or withdrawal) citation is reported together with the article citation)}

(1) Abou-Madina MM, Özcan M, Abdelaziz KM. 2012. Influence of resin cements and aging on the fracture resistance of IPS e.max press posterior crowns. Int J Prosthodont. 25(1):33-5. Retraction notice: Int J Prosthodont. 2012 Mar-Apr; 25(2):109.

(2) Afshar H, Nakhjavani YB, Ahmadi R. 2014. The effect of using different rinsing angles on the micro-tensile bond strength of the sealant to the etched enamel. Contemp Clin Dent. 2014 5(1):67-70. Retraction notice: Contemp Clin Dent. 2016 Jan-Mar; $7(1): 125$.

(3) Agrawal KK, Singh SV, Rashmikant US, Singh RD, Chand P. 2011. Prosthodontic rehabilitation in Sjogren's syndrome with a simplified palatal reservoir: two year follow up. J Prosthodont Res. 55(4):248-51.

(4) Ali SM, Nair R, Shetty RS, Karthikeyan M, Nair A, Sial S. 2013. Influence of post fit and post length on fracture resistance: an in vitro study. J Contemp Dent Pract. 14(3):496-500. Retraction notice: J Contemp Dent Pract. 2013 Sep 1; 1 4(5): 1008. Retraction notice: J Contemp Dent Pract. 2013 Sep 1; 1 4(5):1008.

(5) Alvarez C, Benítez A, Rojas L, Pujol M, Carvajal P, Díaz-Zúñiga, et al. 2015. Differential expression of CC chemokines (CCLs) and receptors (CCRs) by human T lymphocytes in response to diferente Aggregatibacter actinomycetemcomitans serotypes. J Appl Oral Sci. 23(6):580-90. Retraction notice: J Appl Oral Sci. 2016 Feb;24(1):105. Retraction notice: J Appl Oral Sci. 2016 Feb;24(1):105.

(6) Alves da Cunha Tde M, Correia de Araújo RP, Barbosa da Rocha PV, Pazos Amoedo RM. 2012. Comparison of fit accuracy between Procera custom abutments and three implant systems. Clin Implant Dent Relat Res. 14(5):772-7. Notice of withdrawal: Clin Implant Dent Relat Res. 2016 Apr; 18(2):421.

(7) Asgary S, Eghbal MJ. 2010. A clinical trial of pulpotomy vs. root canal therapy of mature molars. J Dent Res. 89(10):1080-5. Retraction notice: J Dent Res. 2011 Sep; 90(9): 1145.

(8) Atri M, Srivastava D, Kharbanda J, Bugalia A, Yousuf A, Anup N. 2015. Occupational Stress, Salivary Cortisol, and Periodontal Disease: A Clinical and Laboratory Study. J Int Oral Health. 7(9):65-9. Retraction notice: J Int Oral Health 2016 May;8(5): 650.

(9) Azadani PN, Jafarimehr E, Shokatbakhsh A, Pourhoseingholi MA, Ghougeghi A. 2007. The effect of dental overbite on eustachian tube dysfunction in Iranian children. Int J Pediatr Otorhinolaryngol. 71(2):325-31. Retraction notice. Int J Pediatr Otorhinolaryngol. 2007 Nov; 71(11): 1815.

(10) Aziz Aly LA, Menoufy HE, Ragae A, Rashed LA, Sabry D. 2012. Adipose stem cells as alternatives for bone marrow mesenchymal stem cells in oral ulcer 
healing. Int J Stem Cells. 5(2):104-14. Retraction notice: Int J Stem Cells. 2014 Nov; $7(2): 167$.

(11) Baghele ON. 2012. Buccinator muscle repositioning. J Indian Soc Periodontol. 16(3):456-60. Retraction notice: J Indian Soc Periodontol. 2012 Oct; 16(4):vi.

(12) Banerjee S, Chakraborty N, Singh R, Gupta T. 2012. Full-mouth rehabilitation of a patient with severe attrition using the Hobo twin-stage procedure. Contemp Clin Dent. 3(1):103-7. Retraction notice: Contemp Clin Dent. 2013 Jul; 4(3): 396.

(13) Bansal S, Shetty S, Bablani D, Kulkarni S, Kumar V, Desai R. 2011. Florid osseous dysplasia. J Oral Maxillofac Pathol. 15:197-200. Retraction notice: J Oral Maxillofac Pathol. 2012 Sep;16(3):353.

(14) Bansal P, Bansal P. 2014. Reconstructive surgery with chin block graft and esthetic rehabilitation of missing anterior tooth. J Indian Soc Periodontol. 18(2):263-6. Retraction notice: J Indian Soc Periodontol. 2014 Jul; 18(4): 425.

(15) Barodiya A, Banda NR, Banda VR, et al. Maxillary adenomatoid odontogenic tumour. BMJ Case Rep. Published Online:14 Jun 2013. doi: 10.1136/bcr-2013010004. Retraction notice: BMJ Case Reports 2013; doi: 10.1136/bcr-2013-010004r.

(16) Barros SE, Janson G, Chiqueto K, Ferreira ES, Janson M. 2012. Selective use of hand and forearm muscles during bone screw insertion: a natural torque meter. $\mathrm{J}$ Oral Maxillofac Surg. 70(11):e598-607. Retraction notice: J Oral Maxillofac Surg. 2013 May; 71(5): 981.

(17) Batista RM, Rosetti EP, Zandonade E, Roelke LH, Vettore MV, Emmerich AO. 2012. Association between periodontal disease and subclinical atherosclerosis: the ELSA-Brasil study. Cad Saúde Pública. 28(5): 965-976. Retraction notice: Cad Saude Publica. 2012 Aug;2 8(8):1613.

(18) Bembi S, Bembi Narula N, Sood A, Gambhir A. 2013. To Evaluate the Effect of Different Adhesive Materials on the Microleakage of Bonded Amalgam Restorations: An in vitro Study. Int J Clin Pediatr Dent. 6(2):95-9.

(19) Bhola R, Su F, Krull CE. 2011. Functionalization of titanium based metallic biomaterials for implant applications. J Mater Sci Mater Med. 22(5):1147-59. Retraction notice: J Mater Sci Mater Med. 2011 Dec; 22(12):2833.

(20) Bilgili D, Yilmaz S, Dumani A, Yoldas O. Postoperative pain after irrigation with Vibringe versus a conventional needle: a randomized controlled trial. Int Endod J. 2016 Aug;49(8):813. doi: 10.1111/iej.12615. Retraction notice: Int Endod J. 2016 Aug; 49(8):813.

(21) Boonanantanasarn K, Janebodin K, Suppakpatana P, Arayapisit T, Rodsutthi JA, Chunhabundit P, Boonanuntanasarn S, Sripairojthikoon W. 2014. Morinda citrifolia leaves enhance osteogenic differentiation and mineralization of human 
periodontal ligament cells. Dent Mater J. 33(1):149. Dent Mater J. 2012;31(5):863-71. Retraction notice: Dent Mater J. 33(1): 149.

Cai C, Rodepeter FR, Rossmann A, Teymoortash A, Lee JS, Quint K, Di Fazio P, Ocker M, Werner JA, Mandic R. 2011. Nef from SIV(mac239) decreases proliferation and migration of adenoid-cystic carcinoma cells and inhibits angiogenesis. Oral Oncol. 47(9):847-54. Retraction notice: Oral Oncol. 2012 Jan;48(1):95.

(23) Chopra R, Mathur S. 2013. Probiotics in dentistry: A boon or sham. Dent Res J. 10:302-6. Retraction notice: Dent Res J (Isfahan). 2014 May;11(3):308. Retraction notice: Dent Res J (Isfahan). 2014 May;11(3):308.

(24) Chopra V, Chopra H, Sharma A. 2013. Allergic urticaria: a case report of rare skin allergy with a common mouthwash. Indian J Dermatol. 58(1):85. Retraction notice: Indian J Dermatol. 2013 Jul;58(4):298.

(25) Cintra LTA, Benetti F, Ferreira LL, Rahal V, Ervolino E, Jacinto RC, et al . 2016. Evaluation of an experimental rat model for comparative studies of bleaching agents. J Appl Oral Sci. 24(2):171-80. Retraction notice: J Appl Oral Sci. 2016 MayJun; 24(3): 308.

(26) Cuoghi OA, Sella RC, de Mendonça MR. 2010. "Mesiodistal angulations of the mandibular canines, premolars and molars with or without the presence of third molars". Eur J Orthod. 32(4):472-6. Retraction notice: Eur J Orthod. 2016 Apr;38(2):225.

(27) de Almeida-Gomes F, Carvalho-Sousa B, Furtado-Leite MC, dos Santos RA, Maniglia-Ferreira C. 2008. Effectiveness of single- versus multiple-visit endodontic treatment of two mandibular central incisors from the same patient. Aust Endod J. 34(2):76. Retraction notice: Aust Endod J. 2008; 34(2): 76.

(28) de Meireles DA, de Brito TC, Marques AA, Garrido AD, Garcia LF, Sponchiado EC Jr. 2015. Micro-computed tomography evaluation of apical transportation and centring ability of Reciproc and WaveOne systems in severely curved root canals. Int Endod J. 48(8):814. Retraction notice: Int Endod J. 2015 Aug; 48(8): 814.

(29) Deng T, Wang L, Lv J, Pang J, Liu B, Du Y, Ke J. 2011. Association of three bacterial species and periodontal status in Chinese adults: an epidemiological approach. J Clin Microbiol. 49(1):184-8. Retraction notice: J Clin Microbiol. 2011 May;49(5):2082.

(30) Deshmukh SP, Radke UM. 2012. Translation and validation of the Hindi version of the Geriatric Oral Health Assessment Index. Gerodontology. 29(2):e1052-8. Retraction notice: Gerodontology 2012 Sep;29(3):243. 
(31) Dionysopoulos D, Koliniotou-Koumpia E, Helvatzoglou-Antoniades M, Kotsanos N. 2013. Fluoride release and recharge abilities of contemporary fluoridecontaining restorative materials and dental adhesives. Dent Mater J. 32(2):296-304. Retraction notice: Dent Mater J. 2015; 34(3): 410.

(32) Ellakwa AE, El-Sheikh AM. 2006. Effect of chemical disinfectants and repair materials on the transverse strength of repaired heat-polymerized acrylic resin. J Prosthodont.15:300-305. Retraction notice: J Prosthodont. 2013 Jun;22(4):341.

(33) El Chaar E, Bettach R. 2011. Immediate placement and provisionalization of implant-supported, single-tooth restorations: a retrospective study. J Oral Implantol. doi: 10.1563/AAID-JOI-D-11-00071. Epub 2011 Sep 9. Retraction notice: J Oral Implantol. 2012 Aug;38(4):434.

(34) El Fadl KA, Ragy N, El Batran M, Kassem N, Nasry SA, Khalifa R, Sedrak H, Isenovic ER. 2011. Periodontitis and cardiovascular disease: Floss and reduce a potential risk factor for CVD. Angiology. 62(1):62-7. Retraction notice: Angiology 2011 May; 62(4): 352.

(35) El-Sheikh AM, Shihabuddin OF, Ghoraba SM. 2012. A prospective study of early loaded single implant-retained mandibular overdentures: preliminary one-year results. Int J Dent. 2012;2012:236409. doi: 10.1155/2012/236409. Epub 2012 Mar 15. Retraction notice: Int J Dent. 2013;2013:310726.

(36) Fee L. Socket preservation. Br Dent J. 2017 Apr 21;222(8):579-582. doi: 10.1038/sj.bdj.2017.355. Retraction notice: Br Dent J. 2017 Nov 10;223(9):741.

(37) Feng L, Li H, E LL, Li CJ, Ding Y. 2014. Pathological changes in the maxillary sinus mucosae of patients with recurrent odontogenic maxillary sinusitis. Pak J Med Sci. 30(5):972-5. Retraction notice: Pak J Med Sci .2016 May-Jun; 32(3): 795.

(38) Gathecha G, Makokha A, Wanzala P, Omolo J, Smith P. 2012. Dental caries and oral health practices among 12 year old children in Nairobi West and Mathira West Districts, Kenya. Pan Afr Med J. 12:42. Retraction notice: Pan Afr Med J. 2015 Nov 11; 22:233.

(39) Gerlach KL, Schwarz A. 2003. [Load resistance of mandibular angle fracturs treated with a miniplate osteosynthesis]. Mund Kiefer Gesichtschir. 7(4):241-5. Retraction notice: Oral Maxillofac Surg. 2012 Dec;16(4):405.

(40) Gill JS, Gill S, Bhardwaj A, Grover HS. 2012. Oral haemangioma. Case Rep Med. 2012:347939. doi: 10.1155/2012/347939. Retraction notice: Case Rep Med. 2014; 2014:942352.

(41) Goenka P, Dutta S, Marwah N. 2011. Biological approach for management of anterior tooth trauma: triple case report. J Indian Soc Pedod Prev Dent. 29(2):180-6. Retraction notice: J Indian Soc Pedod Prev Dent. 2012 Jul-Sep;30(3):282. 
(42) Gopikrishna V, Baweja PS, Venkateshbabu N, Thomas T, Kandaswamy D. 2008. Comparison of coconut water, propolis, HBSS, and milk on PDL cell survival. J Endod. 34(5):587-9. Retraction notice: J Endod. 2014 Feb;40(2):290.

(43) Granström G. 2009. Middle ear infections. Periodontol 2000. 49:179-93. Retraction notice: Periodontol 2000. 2009;51:276.

(44) Guilleminault C, Quo S, Huynk N, Li K. 2008. Orthodontic expansion treatment and adenotonsillectomy in the treatment of obstructive sleep apnea in prepubertal children. Sleep 31(7): 953-957. Retraction notice: Sleep Jan; 33(1): 8.

(45) Gulsahi A, Paksoy CS, Ozden S, Kucuk NO, Cebeci ARI, Genc Y. Assessment of bone mineral density in the jaws and its relationship to radiomorphometric indices. Dentomaxillofac Radiol 2010; 39: 284-289. Retraction notice: Dentomaxillofac Radiol 2010 2013; 42(8): 20139012.

(46) He Y, Chen F, Cai Y, Chen S. 2015. Knockdown of tumor protein D52-like 2 induces cell growth inhibition and apoptosis in oral squamous cell carcinoma. Cell Biol Int. 39(3):264-71. Retraction notice: Cell Biol Int 2016 Mar; 40(3): 361.

(47) Hiremath VP, Rao CB, Naiak V, Prasad KV. 2013. Anti-inflammatory effect of vitamin D on gingivitis: a dose response randomised controlled trial. Indian J Public Health. 57(1):29-32. Retraction notice: Indian J Public Health. 2013 Apr-Jun; 57(2): 77.

(48) Huang HH, Lin MC, Lin CC, Lin SC, Hsu CC, Chen FL, Lee SY, Hung CC. 2006. Effects of welding pulse energy and fluoride ion on the cracking susceptibility and fatigue behavior of Nd:YAG laser-welded cast titanium joints. Dent Mater J. 25(3):632-40. Retraction notice: Dent Mater J 2013; 32(1): 195.

(49) Hwang JTK, Gu YR, Dickson BJ, Shen M, Ralhan R, Walfish PG, Mock D, Pritzker KPH. Straticyte demonstrates prognostic value over oral epithelial dysplasia grade for oral potentially malignant lesion assessment. Oral Oncol. 2017 Sep;72:1-6. doi: 10.1016/j.oraloncology.2017.06.024. Retraction notice: Oral Oncol. 2018 Feb;77:138.

(50) Jacinto-Alemán LF, García-Carrancá A, Leyba-Huerta ER, Zenteno-Galindo E, Jiménez-Farfán MD, Hernández-Guerrero JC. 2013. ErbB expression changes in ethanol and 7,12- dimethylbenz (a)anthracene-induced oral carcinogenesis. Med Oral Patol Oral Cir Bucal. 18(2):e325-31. Retraction notice: Med Oral Patol Oral Cir Bucal. 2014 Jan 1;19(1):e98.

(51) Jin H, Patil PM, Sharma A. 2014. Topical review: the enigma of fibromyalgia. J Oral Facial Pain Headache. 28(2):107-18. Retraction notice: J Oral Facial Pain Headache. 2014 Fall;28(4):preceding 297.

(52) Khattab AM, El-Seify ZA, Shaaban A, Radojevic D, Jankovic I. 2010. Sevoflurane-emergence agitation: effect of supplementary low-dose oral ketamine 
premedication in preschool children undergoing dental surgery. Eur J Anaesthesiol. 27(4):353-8. Retraction notice: Eur J Anaesthesiol. 2011 Apr;28(4):310.

(53)

Khung R, Suansuwan NS. Effect of gold sputtering on the adhesion of porcelain to cast and machined titanium. J Prosthet Dent. 2013 Jul;110(1):41-6. doi: 10.1016/S0022-3913(13)60337-6. Retraction notice: Arch Otolaryngol Head Neck Surg. 2012 May;138(5):525.

(54) Kim JK, Cho JH, Lee YJ, Kim CH, Bae JH, Lee JG, Yoon JH. 2010. Anatomical variability of the maxillary artery: findings from 100 Asian cadaveric dissections. Arch Otolaryngol Head Neck Surg. 136(8):813-8. Retraction notice: Arch Otolaryngol Head Neck Surg. 2012May; 138(5): 525.

(55) Koduganti RR, Sandeep N, Guduguntla S, Chandana Gorthi VS. 2011. Probiotics and prebiotics in periodontal therapy. Indian J Dent Res. 22(2):324-30. Retraction notice: Indian J Dent Res. 2012 Sep-Oct;23(5):682.

(56) Kolaparthy LK, Sanivarapu S, Swarna C, Devulapalli NS. 2014. Neutrophil extracellular traps: Their role in periodontal disease. J Indian Soc Periodontol. 18:6937. Retraction notice: J Indian Soc Periodontol. 2015 Mar-Apr;19(2):128.

Kulkarni VK, Deshmukh J, Banda NR, et al. Odontomas-silent tormentors of teeth eruption, shedding and occlusion. BMJ Case Rep. Published Online: 14 Dec 2012. doi: 10.1136/bcr-2012-007666. Retraction notice: BMJ Case Rep. 2013 Aug 29;2013. pii: bcr2012007666rp.

(58) Kumar S, Atray D, Paiwal D, Balasubramanyam G, Duraiswamy P, Kulkarni S. 2010. Dental unit waterlines: source of contamination and cross-infection. J Hosp Infect. 74(2):99-111. Journal of Hospital Infection. Volume 78, Issue 4, August 2011, Page 340 .

(59) Kumar NS, Prabu PS, Prabu N, Rathinasamy S. 2012. Sealing ability of lateral condensation, thermoplasticized gutta-percha and flowable gutta-percha obturation techniques: A comparative in vitro study. J Pharm Bioallied Sci. 4(Suppl 2):S131-5. Retraction notice: J Pharm Bioallied Sci. 2015 Aug; 7(Suppl 2): S830.

(60) Kumar S, Arora A, Yadav R. 2012. Prosthetic rehabilitation of edentulous patient with limited oral access: A clinical report. Contemp Clin Dent. 3(3):349-51. Retraction notice: Contemp Clin Dent. 2016 Jan-Mar;7(1):124.

(61) Kurtulmus H, Cotert HS. 2009. Management of obstructive sleep apnea in an edentulous patient with a combination of mandibular advancement splint and tongueretaining device: a clinical report. Sleep Breath. 13(1):97-102. Retraction notice: Sleep Breath 2011 Jan;15(1):153.

(62) Lin F, Yao L, Bhikoo C, Guo J. 2016. Impact of fixed orthodontic appliance or clear-aligner on daily performance, in adult patients with moderate need for treatment. 
Patient Prefer Adherence. 10:1639-45. Retraction notice: Patient Prefer Adherence. 2016 Nov 10;10:2321.

(63)

Lin F, Yao L, Xiao J, Liu D, Ni Z. 2014. MiR-206 functions as a tumor suppressor and directly targets K-Ras in human oral squamous cell carcinoma. Onco Targets Ther. 7:1583-91. Retraction notice: Onco Targets Ther. 2016 Oct 20;9:6377.

(64)

Lv J, Zhu YX, Liu YQ, Xue X. 2015. Distinctive pathways characterize A. actinomycetemcomitans and P. gingivalis. Mol Biol Rep. 42(2):441-9. Retraction notice: Mol Biol Rep 2015 Oct; 42(10):1499.

(65) Mahmoudi M, Saidi A, Gandjalikhan Nassab SA, Hashemipour MA. 2012. A three-dimensional finite element analysis of the effects of restorative materials and post geometry on stress distribution in mandibular molar tooth restored with post-core crown. Dent Mater J. 31(2):171-9. Retraction notice: Dent Mater J. 2014; 33(1):147.

(66) Mansuri S, Abdulkhayum AM, Gazal G, Hussain MA. 2013. Treatment of mandibular angle fracture with a $2 \mathrm{~mm}, 3$ dimensional rectangular grid compression miniplates: A prospective clinical study. J Int Oral Health. 5(6):93-100.

(67) Mansuri S, Mujeeb A, Hussain SA, Hussain MA. Mandibular third molar impactions in male adults: Relationship of Operative time and Types of impaction on inflammatory complications. J Int Oral Health. 2014 Apr;6(2):9-15. Epub 2014 Apr 26. Retraction notice: J Int Oral Health. 2016 Jul;8(7):838.

(68) Maroli S, Srinath HP, Goinka C, Yadav NS, Bhardwaj A, Varghese RK. 2014. Sniffing out pain: An in vivo intranasal study of analgesic efficacy. J Int Oral Health. 6(1):66-71. . Retraction notice: J Int Oral Health. 2014 Jul; 6(4):111.

(69) Moghe S, Saini N, Moghe A. 2012. Platelet-rich plasma in periodontal defect treatment after extraction of impacted mandibular third molars. Natl J Maxillofac Surg. 3:139-43. Retraction notice: Natl J Maxillofac Surg 2012 Jul;3(2):139-4.

(70) Clin Oral Implants Res. doi: 10.1111/j.1600-0501.2012.02433.x. Retarcation notice: Moll D. 2012. Telescopic crown-retained removable partial dentures on teeth and implants: An 8- to 9-year prospective randomized clinical trial. Clin. Oral Implants Res. 23(7):895.

(71) Moshonov J, Peretz B, Brown T, Rotstein I. 2003. Cleaning of the Root Canal Using Nd:YAP Laser and Its Effect on the Mineral Content of the Dentin. J. Clin. LaserMedicine Surg. 21(5):279-282. Photomed Laser Surg. 2015 Nov;33(11):576.

(72) Nakano M, Fujii Y. 2003. Prevention of nausea and vomiting after dental surgery: a comparison of small doses of propofol, droperidol, and metoclopramide. Can. J. Anesth. 50(10):1085. Retraction notice: Can J Anaesth. 2013 Jun;60(6):608.

(73) Naqvi N, Naqvi R, Wong C, Pearce S. 2008. A novel observation of pubic osteomyelitis due to Streptococcus viridans after dental extraction: a case report. J. Med. Case Rep. 2(255):1-4. Retraction notice: J Med Case Reports. 2009; 3: 122. 
(74) Nayyar AS, Khan M, Bafna UD, Ahmed S, Chaluvaiah GH. 2014. Colposcopy in oral epithelial dysplasia: seeing the unseen, a pilot study. J Cancer Res Ther. 10(3):563-70. Retraction notice: J Cancer Res Ther. 2015 Oct-Dec;11(4):1049.

(75) Nayar S, Bhuminathan S, Mahadevan R. 2015. Combination restoration in full mouth rehabilitation. J Pharm Bioallied Sci 7(S1):S288-S290. Retraction notice: J Pharm Bioallied Sci 2016 Oct;8(Suppl. 1): S192.

(76) Nerkar R, Yadav S, Mehta V, Joshi P. 2015. Root Canal Preparation in Primary Teeth with Nickel-Titanium Rotary Files: A Review. Journal of Advanced Oral Research. 6(2):1-4. Retraction notice: Journal of Advanced Oral Research (JoAOR). Year : 2015 | Volume : Volume 6 | Issue : Issue 3 | Pages : 55-55.

(77) Nekora-Azak A. 2004. Temporomandibular disorders in relation to female reproductive hormones: A literature review. J. Prosthet. Dent. 91:491-493. Retraction notice: J. Prosthet. Dent. 2005, 94(3): 305.

(78) Ni ZY, Lin FO, Liu DF, Xiao J. 2015. Decreased microRNA-143 expression and its tumor suppressive function in human oral squamous cell carcinoma. Genet Mol Res. 214(2):6943-52. Retraction notice: Genet Mol Res 2016 Dec 1; 15(4).

(79) Nikitakis N, Scheper M, Papanikolaou V, John S. 2009. The oncogenic effects of constitutive Stat 3 signaling in salivary gland cancer cells are mediated by survivin and modulated by the NSAID sulindac. Oral Surg. Oral Med. Oral Pathol. Oral Radiol. 107:826-836. Retraction notice: Oral Surg Oral Med Oral Pathol Oral Radiol. 2014 Dec;118(6):746.

(80) Nosrati K, Seyedmajidi M. 2009. Ameloblastomatous calcifying odontogenic cyst: a case report of a rare histologic variant. Arch Iran Med 12(4):417-20. Retraction notice: Arch Iran Med 2010 Mar; 13(2):174.

(81) Numazaki M, Fujii Y. 2005. Reduction of postoperative emetic episodes and analgesic requirements with dexamethasone in patients scheduled for dental surgery. $\mathrm{J}$. Clin. Anesth. 17:182-186. Retraction notice: J. Clin. Anesth 2013 Jun;25(4):354.

(82) Ozawa A1, Tada H, Sugawara Y, Uehara A, Sasano T, Shimauchi H, et al. 2004. Endogenous IL-15 Sustains Recruitment of IL-2R $\beta$ and Common $\gamma$ and IL-2Mediated Chemokine Production in Normal and Inflamed Human Gingival Fibroblasts. J. Immunol. 173:5180-5188. Retraction notice: J. Immunol.2009 Aug 1; 183(3): 2193.

(83) Palenik CJ. 2012. The effect of long-term disinfection on clinical contact surfaces. J. Am. Dent. Assoc. 143(5):472-477. Retraction notice: 2012 Sep; 143(9): 968-9.

(84) Panaite D, Klokkevold P, and Charles A. 2008. The Peri-Implant Papilla: Realities on Papilla Preservation and Reformation. J Calif Dent Assoc. 36(11):851-67. Retraction notice: J Calif Dent Assoc 2009 Feb;37(2):71.

(85) Panagiotopoulou O, Curtis N, O’ Higgins P, Cobb SN. 2010. Modelling subcortical bone in finite element analyses: A validation and sensitivity study in the 
macaque mandible. J. Biomech. 43(8):1603-11. Retraction notice: J. Biomech. 2015 Apr 13; 48(6): 1233.

(86) Passi D, Singh G, Dutta S, Sharma S, Mishra S, Gupta C. 2016. Extract as Medicament for Treatment of Dry Socket: An Ancient Remedy Rediscovered?Case Series and Literature Review. J. Maxillofac. DOI 10.1007/s12663-014-0692-y. Retraction notice: Oral Surg. 15(3):345-345. epidermoid cyst: A case report, differential diagnosis and therapy. Contemp. Clin. Dent. 5(2):252. Retraction notice: Contemp. Clin. Dent 2015; 6(3): 437.

(88) Pedaballi P, Sundaram R, Ramachandran M. 2012. Prevalence of gingival enlargement secondary to calcium channel blockers in patients with cardiovascular diseases J Indian Soc Periodontol. 2012 Jul-Sep; 16(3): 430-435. Retracted notice:J. Indian Soc. Periodontol. 16(3):430.

(89) Pendyala G, Joshi S, Chaudhari S, Gandhage D. 2013. Links demystified: Periodontitis and cancer. Dent. Res. J. (Isfahan). 10(6):704-712. Retraction notice: Dent. Res. J. (Isfahan ) 2014 May; 11(3): 308

(90) Peng J-P, Chang H-C, Hwang C-F, Hung W-C. 2005. Overexpression of cyclooxygenase- 2 in nasopharyngeal carcinoma and association with lymph node metastasis. Oral Oncol. 41(9):903-908. Retraction notice: Oral Oncol 2006 Jul; 42(6): 653.

(91) Pereira CM, Monteiro MC, Meneghini AJ, Silva GBL, Lelis JL, Botelho TL. Burkitt's lymphoma: clinic progression and prognosis. Two different cases reports in young patients. Rev. odonto ciênc. 2010; 25(4):417-421. Retraction notice: http://dx.doi.org/10.1590/S1980-65232010000400018.

(92) Pieri F, Aldini NN, Fini M, Marchetti C, Corinaldesi G. 2012. Rehabilitation of the Atrophic Posterior Maxilla Using Short Implants or Sinus Augmentation with Simultaneous Standard-Length Implant Placement: A 3-Year Randomized Clinical Trial. Clin. Implant Dent. Relat. Res.2012 Dec 3. Retraction notice: Clin Implant Dent Relat Res. 2012 Dec;14(6):924.

(93) Quinonez R, Stearns S. 2008. Issues and Early Evidence for the Economic Evaluation of the Effects of Periodontal Therapy on Pregnancy Outcomes. J Periodontol 2008;79:203-206. Retraction notice: J. Periodontol. 79(5):771-771.

(94) Rabanal A, Bral M, Goldstein G. Management of a patient with severe erosive lichen planus in need of an immediate complete denture: a clinical report. J Prosthet Dent. 2007 Oct;98(4):256-9. Retraction notice: https://doi.org/10.1016/j.prosdent.2006.10.003.

(95) Rajendran R, Deepthi K, Nooh N, Anil S. 2011. $\alpha 4 \beta 1$ integrin-dependent cell sorting dictates T-cell recruitment in oral submucous fibrosis. J. Oral Maxillofac. Pathol. 15(3):272. Retraction notice: J Oral Maxillofac Pathol. 2012 ; 16(3): 342.

(96) Ramani P, Chandrasekar T, Anuja N, Muthusekar MR, Sherlin HJ, Kulkarni A. 2007. A swelling in the buccal mucosa with intracranial involvement. Oral Surgery, 
Oral Med. Oral Pathol. Oral Radiol. Endodontology 103(3):308-313. Retraction notice: Oral Surg Oral Med Oral Pathol Oral Radiol Endod. 2008 Sep;106(3):463.

(97) Rao MVR, Reddy MV, Sunder Ss, Kiranmai G, Kolasani B, Kumar Kr. 2014. In-dental office screening for diabetes mellitus using gingival crevicular blood. J. Int. Soc. Prev. Community Dent. 4(6):161. Retraction notice: J. Int. Soc. Prev. Community Dent. 2015; 5(5) 432.

(98) Rastogi P. 2015. Emergence of cancer stem cells in head and neck squamous cell carcinoma: A therapeutic insight with literature review: Retraction. Dent Res J (Isfahan). 2012 May;9(3):239-44. Retraction notice: Dent. Res. J. (Isfahan). 12(5):498.

(99) Saker S, El-Kholany N, El-Gendy A, Fadhil ON, Maria OM. Effect of post space conditioning and luting resin on the retentive strength of fiber-reinforced composite resin posts. J Prosthet Dent. 2014 Apr 22. pii: S0022-3913(14)00110-3. Retraction notice: doi: 10.1016/j.prosdent.2013.07.030.

(100) Saker S, El-Kholany N, Sakrana A, Maria OM. Effect of different dentin cleaning techniques on bond strength and the micromorphology of dentin/selfadhesive resin cement interface. J Prosthet Dent. 2014 Apr 29. pii: S00223913(14)00107-3. Retraction notice: doi: 10.1016/j.prosdent.2013.12.015.

(101) Santander S, Alcaine C, Lyahyai J, Pérez MA, Rodellar C, Doblaré M, Ochoa I. 2012. In vitro osteoinduction of human mesenchymal stem cells in biomimetic surface modified titanium alloy implants. Dent. Mater. J. 31(5):843-850. Retraction notice: Dent. Mater. J.2014;33(1):148.

(102) Schwendicke F. 2016. Retracted: Modern Concepts for Caries Tissue Removal J Esthet Restor Dent. 2016 Feb 15. doi: 10.1111/jerd.12201. Epub 2016 Feb 15. Retraction notice: J Esthet Restor Dent. 2016 Mar-Apr;28(2):136. doi: 10.1111/jerd.12213. Epub 2016 Mar 25.

(103) Seyedmajidi M, Feizabadi M. 2009. Peripheral Calcifying Odontogenic Cyst. Arch Iran. Med 12(3):309 - 312. Retraction notice : March Iran Med 2010 Mar; 13(2): 174.

(104) Seyedmajidi M, Feizabadi M. 2008. Squamous Cell Carcinoma of the Tongue in a 13-Year-Old Boy. Arch. Iran. Med. 11(3):341 - 343. Retraction notice: Arch Iran Med. 2008 May 11(3): 341-3. (105)

Shah A, Shah P, Goje SK, Shah R, Modi B. 2017a. Use of CBCT in Orthodontics-A Review. Journal of Medical Research. Vol 1. Nr. 1. Retraction notice: https://jmri.org.in/jmri/article/view/16.

(106) Shah A, Shah P, Goje SK, Shah R, Modi B. 2017b. Functional Appliances in the Treatment of Class II Malocclusion-A Review. Journal of Medical Research. Vol 1. Nr. 1.

(107) Shah AF, Batra M, Ishrat A. Transition in Dental Treatment Utilization in Jammu And Kashmir, India - A 10 Year Retrospective Study. Nepal J Epidemiol. 2017;7(3); 699. Retraction notice: Nepal J Epidemiol Vol.7(3) 2017 pp.699. 
(108) Shetty D, Manchanda A, Urs A, Sirohi Y. 2011b. A color contrast aided density imaging technique to differentiate between dental hard tissues and its relevance. Indian J Dent Res. 2011 Mar-Apr;22(2):266-9. Retraction notice: Indian J Dent Res. 2012 Sep-Oct;23(5):682.

(109) Shetty D, Urs A, Rai H, Ahuja N, Manchanda A. 2010. Case series on vascular malformation and their review with regard to terminology and categorization. Contemp Clin Dent 1(4):259-262. Retraction notice: Contemp Clin Dent. 2012; 3(4): 392.

(110) Shetty DC, Urs AB, Ahuja P, Sahu A, Manchanda A, Sirohi Y. 2011a. Mineralized components and their interpretation in the histogenesis of peripheral ossifying fibroma. Indian J. Dent. Res. 22(1):56-61. Retraction notice: Indian J Dent Res. 2011 Jan-Feb;22(1):56-61.

(111) Sohi R, Gambhir R, Sogi G, Veeresha K, Randhawa A. 2014. Dental health status and treatment needs of police personnel of a North Indian State: A crosssectional study. Ann. Med. Health Sci. Res. 4(4):567. Retraction notice: Ann Med Health Sci Res. 2014 Sep; 4(Suppl 3): S335.

(112) Soodan KS, Priyadarshni P, Singh JP. 2014. Aeronautic dentistry: an upcoming branch. Int. J. Stomatol. Occlusion Med. 7(4):91-96. Retraction notice: https://doi.org/10.1007/s12548-014-0113-3.

(113) Subramani T, Senthilkumar K, Periasamy S, Rao S. 2013. Expression of angiotensin II and its receptors in cyclosporine-induced gingival overgrowth. J. Periodontal Res. 48(3):386-391. Retraction notice: J Periodontal Res. 2014 Apr; 49(2):275.

(114) Subramaniam P, Prashanth P. 2012. Prevalence of early childhood caries in 8 48 month old preschool children of Bangalore city, South India. Contemp Clin Dent. 2012 Jan;3(1):15-21. Retraction notice: Contemp Clin Dent. 2014 Apr;5(2):169.

(115) Sudbo J, Reith A. 2002. When is an oral leukoplakia premalignant? Oral Oncol. 38(8):813-814. Retraction notice: Oral Oncol. 2007 Apr; 43(4): 419.

(116) Sudbo J, Ried T, Bryne M, Kildal W, Danielsen H, Reith A. 2001. Abnormal DNA content predicts the occurrence of carcinomas in non-dysplastic oral white patches. Oral Oncol. 37(7):558-65. Retraction notice: Oral Oncol. 2007 Apr;43(4):418.

(117) Sudbo J, Ristimaki A, Sondresenc J, Kildald W, Boysene M, Koppangf H, et al. 2003a. Cyclooxygenase-2 (COX-2) expression in high-risk premalignant oral lesions. Oral Oncol. 39:497-505. Retraction notice: Oral Oncol. 2007 Apr;43(4):420.

(118) Sudbo J, Bryne M, Mao L, Lotan R, Reith A, Kildal W, Davidson B, Søland TM, Lippman SM. 2003b. Molecular based treatment of oral cancer. Oral Oncol. 39(8):749-58. Retraction notice: Oral Oncol. 2007 Apr;43(4):421.

(119) Sujesh M, Rangarajan V, Ravi Kumar C, Sunil Kumar G. 2012. Stem Cell Mediated Tooth Regeneration: New Vistas in Dentistry. J. Indian Prosthodont. Soc. 
12(1):1-7. Retraction notice: J Indian Prosthodont Soc. 2014 Dec; 14(Suppl.1): 351.

(120) Sumanth KN, Boaz K, Shetty NY. 2008. Glass embedded in labial mucosa for 20 years. Indian J. Dent. Res. 19(2):160-1. Retraction notice: Indian J Dent Res. 2008 Jul-Sep;19(3):281.

(121) Thapar R, Choudhry S, Sinha A, Bali R, Shukla D. 2013. Pink tooth phenomenon: An enigma? J. Forensic Leg. Med. 20(7):912-914. Retraction notice: J Forensic Leg Med. 2016 Feb; 38:122.

(122) Topcu FT, Erdemir U, Sahinkesen G, Mumcu E, Yildiz E, Uslan I. 2010. Retracted: Push-out bond strengths of two fiber post types bonded with different dentin bonding agents. J. Biomed. Mater. Res. Part B Appl. Biomater. 93(2):359-366. Retraction notice: J Biomed Mater Res B Appl Biomater. 2012 Jul; 100(5):1458.

(123) Uehara A, Sugawara S, Muramoto K, Takada H. 2002. Activation of human oral epithelial cells by neutrophil proteinase 3 through protease-activated receptor- 2 . J Immunol. 2169(8):4594-603. Retraction notice: J Immunol. 2010 Apr 1; 184(7): 4042.

(124) Uehara A, Sugawara S, Watanabe K, Echigo S, Sato M, Yamaguchi T, et al. 2003. Constitutive Expression of a Bacterial Pattern Recognition Receptor, CD14, in Human Salivary Glands and Secretion as a Soluble Form in Saliva. Clin. Vaccine Immunol. 10(2):286-292. Retraction notice: Clin Vaccine Immunol. 2010 Apr;17(4):698.

(125) Uehara A, Sugawara Y, Sasano T, Takada H, Sugawara S. 2004. Proinflammatory Cytokines Induce Proteinase 3 as Membrane-Bound and Secretory Forms in Human Oral Epithelial Cells and Antibodies to Proteinase 3 Activate the Cells through Protease-Activated Receptor-2. J. Immunol. 173(6):4179-4189. Retraction note: J Immunol. 2010 Apr 1;184(7):4044.

(126) Vashisht R, Indira R, Ramachandran S, Kumar A, Srinivasan MR. 2013. Role of casein phosphopeptide amorphous calcium phosphate in remineralization of white spot lesions and inhibition of Streptococcus mutans? J. Conserv. Dent. 16(4):342-6. Retraction notice: J Conserv Dent 2016; 19:198.

(127) Venkateswar Rao G, Kanthem RK, Cherukuri G, Korlepara R, Kumari G. 2013. Oro-facial cysticercosis : a rare presentation. J. Parasit. Dis. 37(2):294-294. Retraction notice: J Parasit Dis. 2013 Oct; 37(2): 294.

(128) Vyawahare S, Banda NR, Barodiya A, et al. A rare occurrence of peripheral ossifying fibroma in the first decade of life and its management. BMJ Case Rep. Published Online:15 Mar 2013. doi: 10.1136/bcr-2013-009084. Retraction notice: BMJ Case Rep. 2013; 2013: bcr2013009084rp.

(129) Wang G, Tai B, Huang C, Bian Z, Shang Z, Wang Q, et al. 2008. Establishing a multidisciplinary PBL curriculum in the School of Stomatology at Wuhan University. J. Dent. Educ. 72(5):610-5. Retraction notice: Journal of Dental Education October 2008, 72 (10) e1214. 
(Neuroendocrine) Carcinoma of the Maxillary Sinus. Case Rep. Dent. 2014: doi: 10.1155/2014/463109. Retraction notice: Case Rep Dent. 2014;2014:609802.

(131) Yadav SK, Shrestha S. 2014. Rhinosporidiosis of the Parotid Duct. Case Rep. Dent. 2014: doi: 10.1155/2014/131794. Retraction notice: Case Rep Dent. 2014; 2014:38214.

(132) Yahya S, Benghiat H, Nightingale P, Tiffany M, Sanghera P, Hartley A. 2016. Does Dose to an Oral Mucosa Organ at Risk Predict the Duration of Grade 3 Mucositis after Intensity-modulated Radiotherapy for Oropharyngeal Cancer? Clin Oncol (R Coll Radiol). 28(12):e216-e219. Retraction notice: Clin Oncol (R Coll Radiol). 2016 Apr 25. pii: S0936-6555(16)30063-2. doi: 10.1016/j.clon.2016.04.036.

(133) Yang X, Walboomers XF, Bian Z, Jansen JA, Fan M. 2011. Effects of proinflammatory cytokines on mineralization potential of rat dental pulp stem cells. $\mathrm{J}$ Zhonghua Kou Qiang Yi Xue Za Zhi. 2011 Jul;46(7):406-11. Retraction notice: J Tissue Eng Regen Med. 2011 Oct;5(9):759.

(134) Yang X, Zhang S, Pang X, Fan M. 2012a. Mineralized Tissue Formation by Bone Morphogenetic Protein-7-transfected Pulp Stem Cells. J Endod. 2012 Feb;38(2):170-6. Retraction notice: J Endod. 2012 Jun;38(6):868.

(135) Yang X, Zhang S, Pang X, Fan M 2012b. Pro-inflammatory cytokines induce odontogenic differentiation of dental pulp-derived stem cells. J. Cell. Biochem. 113(2):669-677. Retraction notice: J Cell Biochem. 2012 Aug;113(8):2796.

(136) Yazdi I, Seyedmajidi M, Foroughi R. 2009. Desmoplastic ameloblastoma (a hybrid variant): report of a case and review of the literature. Arch Iran Med. 12(3):304-8. Retraction notice: Arch Iran Med. 2010 Mar; 13(2): 17.

(137) Ye X, Tang G. 2015. Effect of coupling asynchronous acoustoelectric effects on the corrosion behavior, microhardness and biocompatibility of biomedical titanium alloy strips. J. Mater. Sci. Mater. Med. 26(1):5371. Retraction notice: J Mater Sci Mater Med. 2016 Nov; 27(11):173.

(138) Zhang Q, Witter DJ, Bronkhorst EM, Creugers NHJ. 2012. Chewing ability in an adult Chinese population. Clin. Oral Investig. Retraction note: Clin. Oral Investig. 16(5):1511-1511. 


\section{Accepted Manuscript}

Title: An analysis of retractions of dental publications

Authors: Clovis Mariano Faggion Jr, Robert S. Ware, Nikolaos Bakas, Jason Wasiak

PII: $\quad$ S0300-5712(18)30412-3

DOI: $\quad$ https://doi.org/10.1016/j.jdent.2018.09.002

Reference: $\quad$ JJOD 3025

To appear in: $\quad$ Journal of Dentistry

Received date: $\quad 23-5-2018$

Revised date: $\quad 28-8-2018$

Accepted date: $\quad$ 4-9-2018

Please cite this article as: Faggion CM, Ware RS, Bakas N, Wasiak J, An analysis of retractions of dental publications, Journal of Dentistry (2018), https://doi.org/10.1016/j.jdent.2018.09.002

This is a PDF file of an unedited manuscript that has been accepted for publication. As a service to our customers we are providing this early version of the manuscript. The manuscript will undergo copyediting, typesetting, and review of the resulting proof before it is published in its final form. Please note that during the production process errors may be discovered which could affect the content, and all legal disclaimers that apply to the journal pertain. 